\title{
PCR Optimization for Beginners: A Step by Step Guide
}

\author{
Saaim Asif1,2 (D), Maaz Khan' ${ }^{1}$, Muhammad Waqar Arshad³ ${ }^{3}$, Muhammad Imran Shabbir ${ }^{*}$ (D) \\ 1. Department of Biological Sciences, Faculty of Basic and Applied Sciences, International Islamic University, Islamabad, Pakistan. \\ 2. Department of Biosciences, Faculty of Life Sciences, COMSATS University, Park Road Chak Shahzad, Islamabad, Pakistan. \\ 3. Department of Molecular Biology, Faculty of Basic Medical Sciences, Shaheed Zulfiqar Ali Bhutto Medical University, Islamabad, Pakistan.
}

$\begin{gathered}\text { Use eour device toscan } \\ \text { and read the artice online }\end{gathered}$
Citation Asif S, Khan M, Arshad MW, Shabbir MI. PCR Optimization for Beginners: A Step by Step Guide . Research in
Molecular Medicine. 2021; 9(2):81-102. https://doi.org/10.32598/rmm.9.2.1189.1

\section{(1) (8)}

Article Type:

Research Paper

Article info:

Received: 24 Mar 2021

Revised: 19 Apr 2021

Accepted: 30 Apr 2021

Keywords:

Polymerase Chain Reaction (PCR), Molecular biology, Genetics, Methods

\begin{abstract}
A B S T RA C T
Background: The invention of Polymerase Chain Reaction (PCR) marked a breakthrough in biomedical research. Its invention divided the timeline into an era before and after PCR. Because of its multiple applications, it has become a vital tool for clinical researchers and diagnosticians. A effective PCR experiment requires adequate knowledge of each reaction component and stepby-step procedure to attain the optimized results. This research aims to employ optimization strategies that are easy to perform, cost-effective, and do not require PCR kits for the generation of amplicons for TYR, MITF, and SOX10 genes and can be used in sequence analysis.

Materials and Methods: Whole blood samples were used to extract genomic DNA with an inorganic method. DNA quantification was done by spectrophotometry analysis. Optimization strategies were adopted to generate PCR products of candidate genes and visualized by agarose gel electrophoresis. Sanger sequencing was performed to check the quality and specificity of generated amplicons via optimization strategies.

Results: This study demonstrates a novel approach for troubleshooting failed reactions without the use of PCR kits. The result indicated that use of sterilized material and reagents along with optimum $\mathrm{MgCl}_{2}$ concentration $(2.0-3.0 \mathrm{mM})$, DNA quantity $(25 \mathrm{ng} / \mu \mathrm{L})$, and annealing temperature $\left(54-60^{\circ} \mathrm{C}\right)$ are necessary to achieve successful amplification. Sequence analysis revealed no background noise often associated with sequencing results.

Conclusion: Optimizing $\mathrm{MgCl}_{2}$ concentration, DNA quantity, annealing temperature, along with the use of contamination-free material and reagents are essential steps in PCR optimization. Following this guide, anyone lacking proper supervision, and with little or no knowledge of the procedure should attain the desired results.
\end{abstract}

\section{Introduction}

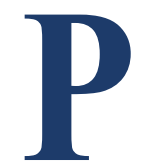

olymerase Chain Reaction (PCR) is a molecular biology technique used for generating multiple copies of a specific DNA segment. The procedure was first demonstrated by Kary Mullis in 1985, while working at Cetus Corporation [1]; however, the initial process was described by Kleppe et al. [2]. PCR works by amplifying a specific segment of DNA template molecule. The technique is not complicated though a successful PCR experiment is difficult to perform on the first try. PCR

\section{* Corresponding Author:}

Muhammad Imran Shabbir, PhD.

Address: Department of Molecular Biology, Faculty of Basic Medical Sciences, Shaheed Zulfiqar Ali Bhutto Medical University, Islamabad, Pakistan. Phone: +92 (51) 9019417

E-mail: imran.shabbir@iiu.edu.pk 
has multiple applications and widely used in biomedical research, forensic sciences, DNA fingerprinting, DNA sequencing, genetic analysis, molecular cloning, molecular diagnostics, and so on [3]. The basic setup for a conventional PCR involves three steps: denaturation, annealing, and extension/elongation. While considering the various reaction components required for a successful PCR setup, the following parameters must be addressed first before starting a PCR experiment to achieve optimized results.

\section{Primer designing}

Primers are short strands of DNA sequences required for the initiation of PCR. The amplification of targeted DNA sequences requires a starting point for the elongation step of the reaction. For the success of the PCR, a set of appropriate primers must be designed. Each primer (forward and reverse) binds to opposite ends of the DNA strands (sense and anti-sense), $5^{\prime} \rightarrow 3^{\prime}$ and $3^{\prime} \rightarrow 5^{\prime}$, respectively (Figure 1). The following parameters must be considered while designing primers for a conventional PCR [4]:

- The specificity and annealing to template depend upon the primer length, and it should neither be too short nor too long. The optimum primer length should be around 14-28 bp for normal PCR and 28-34 bp for multiplex PCR.

- The optimal, Guanine-Cytosine (GC) composition of primers should be between $40 \%$ and $60 \%$.

- A low number of single-base stretches (e.g. TTTTT, or GGGGG) and consecutive di-nucleotides (e.g. TATATATA or CGCGCGCG) should be avoided, as they lead to nonspecific binding and mispairing. Both should be avoided; however, a maximum of four repeated bases and di-nucleotides should be present if necessary.

- A GC- clamp consisting of 4-bases should be present on the 3 ' end of the primer sequence. It is crucial as it enhances primer-template binding and prevents mispairing [5].

- The optimal Melting Temperature $\left(\mathrm{T}_{\mathrm{m}}\right)$ should range between $52^{\circ} \mathrm{C}$ and $60^{\circ} \mathrm{C}$. The temperature range may differ for various targeted sequences. The temperature difference between forward and reverse primers should not be greater than $5^{\circ} \mathrm{C}$ (Further elaboration on the $\mathrm{T}_{\mathrm{m}}$ is provided in the next section).

- An important consideration regarding designing primers is the formation of complementary sequences. The 3' ends of the primers should not complement each other as it will result in hairpin loop structures and primer-dimer formation, resulting in decreased specificity of the reaction [6].

\section{Notable issues}

- Hairpin loop structures arise because of the selfannealing of primers after intra-molecular interaction. They affect the DNA amplification by decreasing primer-template binding, resulting in a low yield of the desired PCR product.

- Production of cross-dimers (Heterodimers) results from annealing between forward and reverse primer and self-dimers (Homodimers) form the interaction of two similar primers with each other.

- Amplification of non-specific products due to cross homology in genomic DNA may decrease the desired amplicon production.

- Strain in primer annealing with a template is due to the relatively different $\mathrm{Tm}$ of each primer.

Tools for primer designing are as follows:

• http://bioinfo.ut.ee/primer3-0.4.0/

- http://perlprimer.sourceforge.net/index.htmL

- https://www.eurofinsgenomics.eu/en/ecom/tools/pcrprimer-design/

- https://www.ncbi.nlm.nih.gov/tools/primer-blast/

Note

To check the selectivity and efficiency of the primers designed, in silico PCR can be performed (https://genome. ucsc.edu/cgi-bin/hgPcr). This theoretical PCR provides information on the size of the amplicon, orientation, and targeted primer location [7]. Computational results are based upon Tm, GC content, secondary structure, and complementarity of the primer sequences. In silico PCR can help determine if primers may anneal to multiple target sites, resulting in amplification of non-targeted sequences and a low number of desired amplicon production.

\section{Melting Temperature $\left(\mathrm{T}_{\mathrm{m}}\right)$}

PCR amplification requires the annealing of primers to targeted DNA sites at a specific $T_{m}$. It is defined as the temperature at which $50 \%$ of double-stranded DNA changes to the single-stranded form. The $T_{m}$ is determined by the concentration, base composition, and length of primers. However, it is also altered by the high GC-content of primers and salt concentration in the reaction mixture [8]. The optimal $\mathrm{T}_{\mathrm{m}}$ should be between 
$52^{\circ} \mathrm{C}$ and $60^{\circ} \mathrm{C}$. The Annealing Temperature $\left(\mathrm{T}_{\mathrm{a}}\right)$ is usually $5^{\circ} \mathrm{C}$ less than the calculated melting temperature. The general formula for manual calculation of $T_{m}$ is given as $\mathrm{T}_{\mathrm{m}} \approx 4(\mathrm{G}-\mathrm{C})+2(\mathrm{~A}-\mathrm{T})$ (Excluding the thermodynamic of the reaction). Changing reaction mixtures by adding additives and modifying cycling conditions can help in attaining optimal $\mathrm{T}_{\mathrm{m}}$.

Tools for calculating $\mathrm{T}_{\mathrm{m}}$ are as follows:

- http://insilico.ehu.es/tm.php?primer

• https://tmcalculator.neb.com/\#!/main

- https://worldwide.promega.com/resources/tools/biomath/tm-calculator/

• https://galaxy.pasteur.fr/forms::melting

- http://mcb.berkeley.edu/labs/krantz/tools/oligocalc. $\mathrm{htmL}$

- http://biotools.nubic.northwestern.edu/OligoCalc. htmL

\section{Equipment and chemicals}

Before the start of the procedure, decontaminate the workbench or table and equipment (micropipettes) by $70 \%$ ethanol solution (Do wear personal protection equipment like latex gloves, safety goggles, and a lab coat to protect and prevent contamination of reagents and equipment). Remember to check if micropipettes are calibrated before use.

\section{Equipment's required}

- Icebox for keeping reagents (Note: if icebox is unavailable, tube rack containing chemical can be placed on a pair of ice packs to maintain temperature).

- Ethanol resistant marker for labeling during the experiment.

- Eppendorf tubes $(1.5$ or $1 \mathrm{~mL})$, PCR tubes $(0.25$ or $0.2 \mathrm{~mL}$ ), and tube rack.

- Pipette tips (variable sizes).

- A set of micropipettes that can dispense in a range between 0.5 and $1000 \mu \mathrm{L}$.

- Thermal cycler.
- Analysis of the PCR amplicon requires performing Agarose Gel Electrophoresis (AGE).

- The following equipment is required for AGE: gel tank with electrodes, gel comb, gel tray, casting dams, power cables, and power supply (Note: gel documentation apparatus is required for gel visualization under UV after AGE).

\section{Chemical used}

- PCR water (PH 7-8), deoxynucleotides (dNTPs), Taq DNA polymerase, reaction buffer, or PCR buffer (may or may not contain $\mathrm{Mg}^{2+}$ ) (Note: concentration and labeling of reagent may differ depending on the manufacturer).

- Set of primers (forward and reverse) for targeted DNA sequences in candidate genes.

- Reagents for AGE include agarose powder, TBE buffer (PH 8.0), Ethidium Bromide (EtBr), distilled water $\left(\mathrm{dH}_{2} \mathrm{O}\right)$, DNA loading dye, and commercially available DNA ladder for amplicon size comparison.

- Additional reagents include betaine, Dimethyl Sulfoxide (DMSO), potassium chloride ( $\mathrm{KCl}$ ), magnesium chloride $\left(\mathrm{MgCl}_{2}\right)$, Bovine Serum Albumin (BSA), and formamide [9]. These compounds may be added in various concentrations for optimization purposes (Note: some manufactures may include an enhancing solution $\mathrm{S}$, excluding the reagents provided, containing these additional reagents in a definite ratio to optimize difficult template amplification, e.g. High GC- content templates).

\section{Primer dilutions}

Primers come in labeled tubes containing lyophilized crystals of primer molecules. Before beginning the PCR experiment, the primer must be diluted in solution form to be incorporated into the reaction mixture. Primer tubes are labeled with a concentration in nanomoles (nmol) for lyophilized form. To make a solution, multiply the value provided in nmol (usually $30-32 \mathrm{nmol}$ ) by 10 , and add the required amount of PCR water $\left(\mathrm{dH}_{2} \mathrm{O}\right)$. For example, if primer concentration is $32 \mathrm{nmol}$, multiply $32 \times 10=$ 320 , and add $320 \mu \mathrm{L}$ of $\mathrm{dH}_{2} \mathrm{O}$ to the lyophilized crystals and gently mix by repeated inversion. The concentration of primers in solutions form will be $100 \mathrm{mM}$ or pmol/ $\mu \mathrm{L}$. Care must be taken while opening tubes containing primers before adding $\mathrm{dH}_{2} \mathrm{O}$, as the lyophilized crystals may fall out due to handling errors. The next step is to make working solutions by diluting primers in a concentration ranging from 10 to $20 \mathrm{mM}$ or pmol $/ \mu \mathrm{L}$, to be 
used in the PCR experiment. Do not use stock solutions directly as this may contaminate original solutions.

\section{Master mix preparation}

- Starting the procedure, arrange all the reagents and chemicals on the workbench in the icebox and allow time to be thawed completely.

- Make a list of all the reagents required and the concentration to be used in the reaction (Table 1). The reagent concentration required may vary depending on the concentrations provided by the manufacturer.

- All reagents must be added into a $1.5 \mathrm{~mL}$ Eppendorf tube for making a master mix solution, from which aliquots can be transferred to each PCR tube.

- Using the equation $\left(\mathrm{M}_{1} \mathrm{~V}_{1}=\mathrm{M}_{2} \mathrm{~V}_{2}\right)$, calculate the volume required from the stock solution to achieve the desired concentration in the final solution. For example, to obtain a $1 \mathrm{X}$ concentration of PCR buffer or reaction buffer in the final master mix of $50 \mu \mathrm{L}$, the volume required from $10 \mathrm{X}$ solution is $5 \mu \mathrm{L}$.

- Add the reaction buffer (as required), to achieve the desired volume of the master mix (Note: the buffer may or may not contain $\mathrm{Mg}^{2+}$ depending on the manufacturer).

- If $\mathrm{Mg}^{2+}$ is not present in the reaction buffer, add $\mathrm{MgCl}_{2}$ separately (Usually provided with the Taq DNA polymerase in the concentration of $15-25 \mathrm{mM}$ ) to the master mix solution as required to obtain the desired volume and concentration [10].

- Add dNTPs to the master mix solution as required to obtain the desired concentration and volume (Note: dNTPs may be in the form of a ready-to-use whole mixture or may be provided separately $[\mathrm{A}, \mathrm{T}, \mathrm{G}$, and $\mathrm{C}]$ by the manufacturer in the concentration of $100 \mathrm{mM}$. They can be combined in a definite ratio to obtain a dNTPs stock solution of $25 \mathrm{mM}$, which can be diluted to form a working solution of $2.5 \mathrm{mM}$, to be used in master mix preparation).

- Add Taq DNA polymerase with a concentration of 0.2-0.5 U as per manufacturers recommendation (Note: polymerase is dissolved in $50 \%$ glycerol solution, to disperse it in the master mix, proper mixing is required by pipetting 10-20 times. Avoid forming bubbles; in case of bubble formation, centrifuge the solution for 10-30 seconds).
- Add PCR water $\left(\mathrm{dH}_{2} \mathrm{O}\right)$ as required to obtain the desired volume of master mix and mix the reagents by pipetting to ensure homogenous dispersal of reagents in solution.

- Aliquot the prepared master mix into each PCR tube and add sample DNA $(25 \mathrm{ng} / \mu \mathrm{L})$ and forward and reverse primer (each $10 \mathrm{pmol} / \mu \mathrm{L}$ ) for the targeted sequence (Table 2).

- Properly mix the components by pipetting $10-15$ times. Avoid bubble formation [11].

- Always prepare a fresh master mix solution before the start of the experiment. Do not leave the master mix overnight in the refrigerator after adding each component, as this may inactivate the Taq DNA polymerase, leading to diminished activity of the amplification reaction (Figure 2).

\section{Note}

Primers and genomic DNA concentration can also be added while preparing the master mix solution. In this case, both have been excluded from Table 1 because the optimization experiments included different primers and various DNA samples.

\section{Cycling conditions}

The basic function of the thermal cycler is to change the temperature of the reaction mixture rapidly. The heat generated is used in DNA denaturation, primer annealing, and extension of targeted sequence resulting in amplicon production. Cycling conditions may differ between targeted sequences because of GC content and template size [12]. The following steps are involved in setting up general cycling conditions for a conventional PCR:

- The first step involves the initial denaturation of the DNA template at $94-96^{\circ} \mathrm{C}$, depending upon the $\mathrm{GC}$ content of DNA and the activity of the DNA polymerase used. Initial denaturation should not exceed 5 minutes, as this may lead to denaturation of DNA polymerase and may result in reaction failure or decreased amplicon production.

- The second step is a loop process consisting of 25-30 cycles in which the reaction undergoes denaturation, annealing, and extension. The first step involves denaturation at $95^{\circ} \mathrm{C}$ for $15-30$ seconds. This time depends on the GC-content of the template and must be kept as short as possible as the DNA template has already gone through an initial denaturation step. The second step is the an- 
Table 1. PCR reagents and their dilutions for master mix preparation

\begin{tabular}{|c|c|c|c|c|c|c|c|c|}
\hline Sr. No. & Reagent & $\begin{array}{l}\text { Conc. of Stock } \\
\text { Solution }\end{array}$ & Conc. Used & $\begin{array}{c}\text { For } 50 \mu \mathrm{L} \\
\text { Master Mix }\end{array}$ & $\begin{array}{l}\text { For } 100 \mu \mathrm{L} \\
\text { Master Mix }\end{array}$ & $\begin{array}{l}\text { For } 150 \mu \mathrm{L} \\
\text { Master Mix }\end{array}$ & $\begin{array}{l}\text { For } 200 \mu \mathrm{L} \\
\text { Master Mix }\end{array}$ & $\begin{array}{l}\text { For } 250 \mu \mathrm{L} \\
\text { Master Mix }\end{array}$ \\
\hline 1 & Reactionv buffer (B) & $10 x$ & $1 \mathrm{X}$ & $5 \mu \mathrm{L}$ & $10 \mu \mathrm{L}$ & $15 \mu \mathrm{L}$ & $20 \mu \mathrm{L}$ & $25 \mu \mathrm{L}$ \\
\hline 2 & $\mathrm{MgCl}_{2}$ & $25 \mathrm{mM}$ & $2.5 \mathrm{mM}$ & $4 \mu \mathrm{L}$ & $8 \mu \mathrm{L}$ & $12 \mu \mathrm{L}$ & $16 \mu \mathrm{L}$ & $20 \mu \mathrm{L}$ \\
\hline 3 & dNTPs & $2.5 \mathrm{mM}$ & $0.2 \mathrm{mM}$ & $4 \mu \mathrm{L}$ & $8 \mu \mathrm{L}$ & $12 \mu \mathrm{L}$ & $16 \mu \mathrm{L}$ & $20 \mu \mathrm{L}$ \\
\hline 4 & Taq DNA polymerase & $5 \mathrm{U} / \mu \mathrm{L}$ & $0.24 \mathrm{U}$ & $0.4 \mu \mathrm{L}$ & $0.8 \mu \mathrm{L}$ & $1.2 \mu \mathrm{L}$ & $1.6 \mu \mathrm{L}$ & $2.0 \mu \mathrm{L}$ \\
\hline 5 & PCR water $\left(\mathrm{dH}_{2} \mathrm{O}\right)$ & $500 \mathrm{~mL}$ & Variable & $13.4 \mu \mathrm{L}$ & $73.2 \mu \mathrm{L}$ & $109.2 \mu \mathrm{L}$ & $146.4 \mu \mathrm{L}$ & $183 \mu \mathrm{L}$ \\
\hline 6 & Total & & & $50 \mu \mathrm{L}$ & $100 \mu \mathrm{L}$ & $150 \mu \mathrm{L}$ & $200 \mu \mathrm{L}$ & $250 \mu \mathrm{L}$ \\
\hline
\end{tabular}

nealing of the primers to the targeted DNA sequence on the template at $54-66^{\circ} \mathrm{C}$ for $30-60$ seconds (Note: The annealing temperature is generally $5^{\circ} \mathrm{C}$ below the $\mathrm{T}_{\mathrm{m}}$ of the primers). The $\mathrm{T}_{\mathrm{a}}$ varies with the length and sequence of primers [13]. High $\mathrm{T}_{\mathrm{a}}$ may prevent primer annealing to the template, whereas a low $\mathrm{T}_{\mathrm{a}}$ may result in the non-specific binding of primers. The third step is the elongation of the template sequence by Taq DNA polymerase. The elongation time and temperature depend on the targeted template and the polymerase used (Note: Increasing the number of cycles $>35$, which may result in amplification of non-targeted sequences) (Table 3 ).

- The third and final step in the PCR cycle is the final elongation/ extension of the targeted sequence by Taq DNA polymerase. This step allows the polymerase to complete the unfinished amplicon and add a 3' residue to the end of the amplicon which may be useful for molecular cloning procedures [14].

- After completing all cycles, the thermal cycler is shifted to a holding temperature, usually for storage purposes and termination of the amplification reaction.

\section{Step by step protocol}

After preparation of reagents and solutions required for a conventional PCR experiment, the following step by step protocol should be followed to achieve an optimized reaction setup:

- Arrange $200 \mu \mathrm{L}$ PCR tubes on a 96-well plate. Then place the plate on an ice bucket or an ice pack and cover the tubes with a lid until used to prevent contamination.

- Now pipette the prepared master mix solution (Table 1) into each PCR tube as required (Table 2).

- Add primers and DNA samples as required. Include a negative control in the experiment, which contains the master mix buffer and primers, but except for the DNA sample. A positive control can also be included, which already contains an amplified PCR product for reference.

- The final reaction volume is adjusted to $20 \mu \mathrm{L}$ for each reaction tube.

Table 2. Recipe for a single reaction in a PCR tube

\begin{tabular}{cc}
\hline Ingredients & Required Volume $(\mu \mathrm{L})$ \\
\hline PCR water $\left(\mathrm{dH}_{2} \mathrm{O}\right)$ & 8.0 \\
\hline Genomic DNA $(25 \mu \mathrm{g} / \mathrm{mL} \mathrm{or} \mathrm{ng} / \mu \mathrm{L})$ & 2.0 \\
\hline Primer forward $(10 \mathrm{pmol} / \mu \mathrm{L}$ or $\mu \mathrm{M})$ & 0.4 \\
\hline Primer reverse ${ }^{*}(10 \mathrm{pmol} / \mu \mathrm{L}$ or $\mu \mathrm{M})$ & 9.2 \\
\hline Master mix buffer $($ From Table 1$)$ & 20 \\
Total & 9.4 \\
\hline
\end{tabular}

*Primer concentration and required volume may vary between manufacturers. Refer to the manufacture's recommendation. 


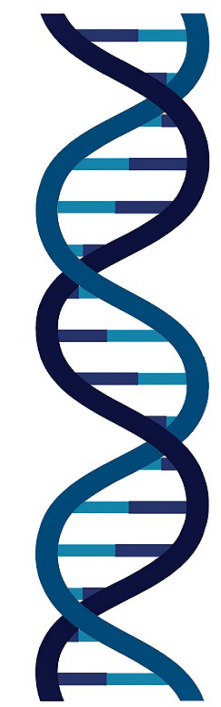

Double Stranded DNA

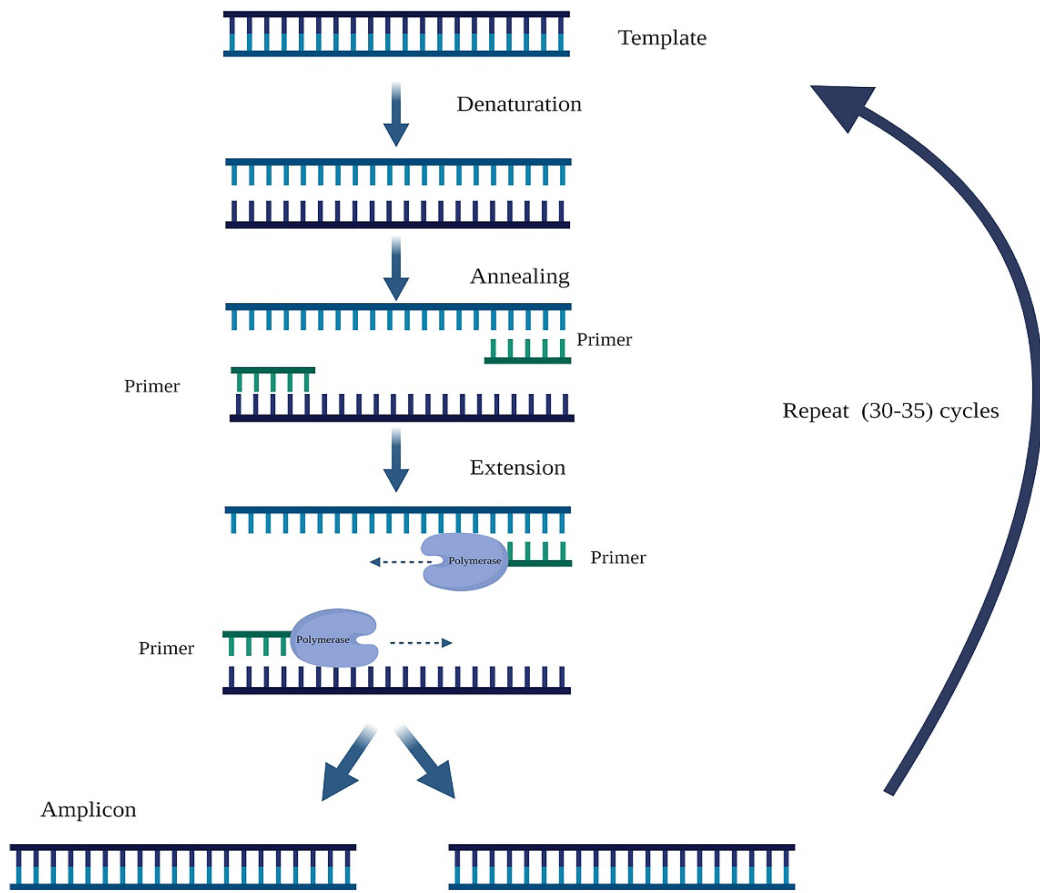

काrmm

Figure 1. General mechanism of three-step PCR cycling

- Tightly cap each PCR tube after the addition of all the reagents to avoid any evaporation.

- Place the tubes containing the reaction mixture into the Thermal cycler and start the cycling program after firmly closing the lid.

- After completion of the cycling program, remove the tubes from the thermal cycler, to be stored at $4{ }^{\circ} \mathrm{C}$ in a refrigerator.

- The PCR products can now be used for AGE and visualized under UV apparatus.

\section{Notes}

- Reagents can be added one by one into each reaction tube, but for ease and convenience, it is recommended to prepare a master mix solution and then aliquot the mixture into each tube. Remember to mix the reaction solution adequately by pipetting to form a homogenous solution.

- After closing the PCR tube, look for any bubbles that may have formed during pipetting. In case of bubble formation, centrifuge the tubes for 10-30 seconds.

- It is important to include a negative and positive control with any PCR experiment. As false positives may be shown in AGE resulting from multiple amplification reactions taking place.

- During AGE, caution is required while handling EtBr, due to its toxicity and mutagenic properties. Always dip the gel slab in a bleach solution before discarding it.

\section{PCR complications}

\section{Smeared bands}

The smearing of bands includes two types: one is the low molecular weight smears and the other one is the high molecular weight smears. DNA template overload or using too much template often leads to smeared bands in PCR. Other reasons may include contamination and too many cycles, which end up in a non-specific product. To overcome this problem, the following steps can be taken:

- Use fresh aliquots and nuclease-free water;

- Decrease DNA template quantity;

- Limit PCR cycles to 25-30;

- Reduce extension time and increase annealing temperature. 
(A)

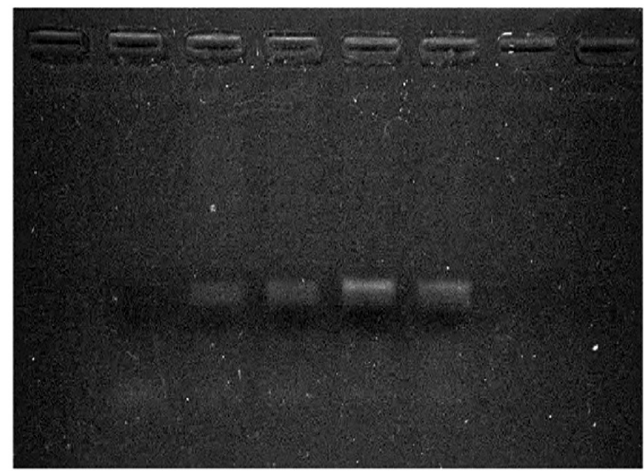

(B)

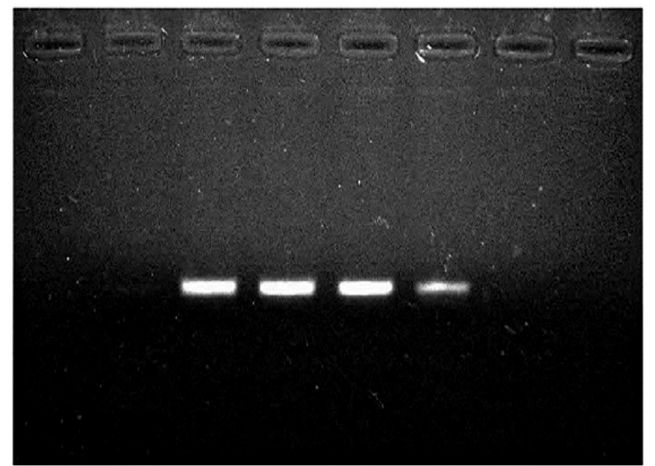

Figure 2. Comparing between the use of stored and freshly prepared master mix

A: $50 \mu \mathrm{L}$ master mix solution stored at $4^{\circ} \mathrm{C}$ overnight before use in PCR experiment yielding faint bands; B: Freshly prepared $50 \mu \mathrm{L}$ master mix used in PCR experiment yielding the production of amplicon of desired size and intensity

\section{Weak or faint bands}

DNA denaturation depends on the provided time. If denaturation time is too short DNA will not completely denature, and the reaction proficiency will be low, while providing a long denaturation time, may lead to degradation of the DNA template. Other causes include using few PCR cycles, short extension time, unstable annealing time, and temperature. If the annealing time is short, primers are unable to bind to the corresponding DNA template, and if the temperature in which annealing happens is high, the primers did not open and lack the required environments in which they bind to the template. Overall, weak or faint bands transpire for several reasons like lacking the required number of cycles, little annealing time, short extension time, enhanced annealing temperature, reduced denaturing temperature, and high or low denaturation time. The following steps can be taken to resolve this issue:

- Increase $\mathrm{MgCl}_{2}$ concentration;

- Increase DNA template quantity;

- Increase the number of PCR cycles;
- Increase primer concentration;

- Increase dNTPs concentratio.

\section{Dimer formation}

Primer Dimers (PDs) are potential results in PCR experiments; as the name infers, PDs comprise primer molecules that have appended (hybridized) to one another due to strings of integral bases in the primers. Therefore, the DNA polymerase amplifies the PDs, leading to competition for PCR reagents, repressing the amplification of the DNA sequence targeted for PCR. AGE of the PCR product may reveal the presence of primer dimers [15]. PDs in EtBr-stained gels are generally seen as a 30-50 bp band or smear of moderate to high intensity and distinct from the bands of targeted sequence, which are often longer than $50 \mathrm{bp}$ [16]. Following are some key optimization strategies to prevent dimer formation:

- Raise the annealing temperature;

- Increase the time/temperature of template denaturation;

- Reduce primers concentration (10 pmol); 
(A)

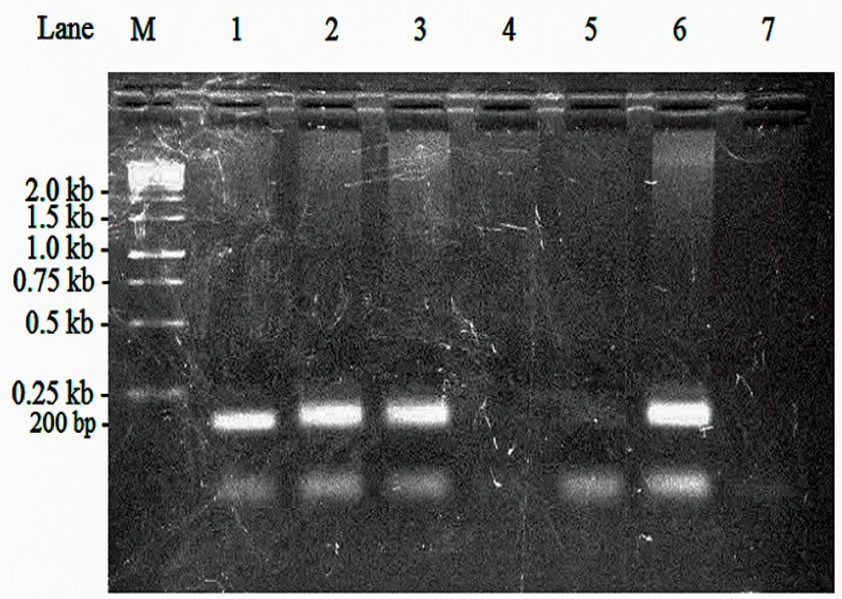

(B)

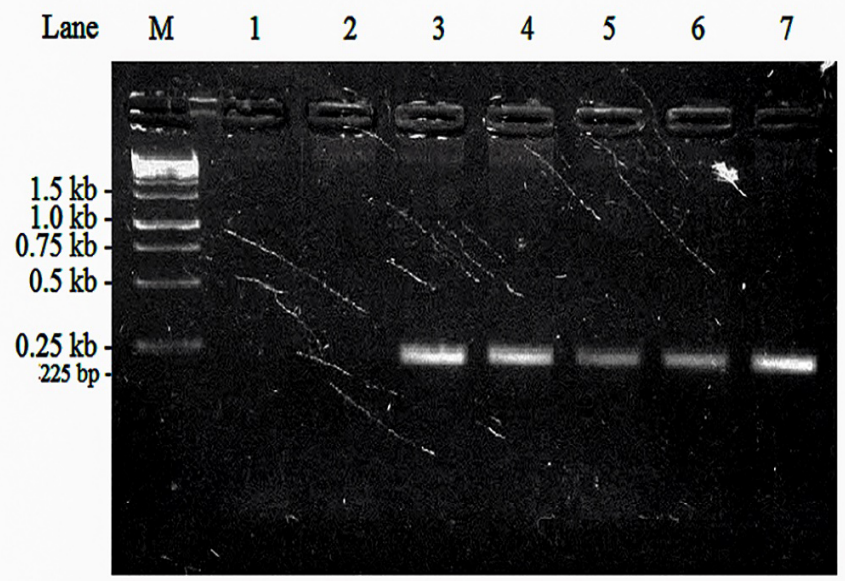

grmm

Figure 3. Comparing between the use of unsterilized and sterilized material

A: Unautoclaved tips and eppendorf tubes used in PCR experiment for amplification of $225 \mathrm{bp}$ segment of the TYR gene from genomic DNA ( $25 \mathrm{ng} / \mu \mathrm{L}$ ) extracted from blood, Resulted in Dimer Formation and Decreased Size of the Amplicon; B: Use of Autoclaved Material Resulted in the Production of desired amplicon size $225 \mathrm{bp}$ segment of the TYR gene.

Lane (M) contains a DNA ladder.

-Use a PCR enhancer such as betaine, DMSO, or formamide;

- Check your template DNA (high concentration and low purity that may cause dimers);

- Use high-quality Taq DNA polymerase [17];

Contaminants in template DNA might inhibit Taq DNA polymerase; using purification kits or diluting the DNA might solve this problem.

- If none of these steps improve your reaction outcome, try to design another set of primers.

\section{One or more bands missing}

A commonly occurring issue associated with PCR is the absence of a single or two bands, which may occur due to the absence of one or more component(s) from the reaction mixture or non-homogenous mixing of master mix solution because of a handling error. To prevent missing bands following steps can be taken:

Add reagents in order, close tube after adding a reagent;

Organized pipetting;

Check the added compounds to cross off the added reagents. 


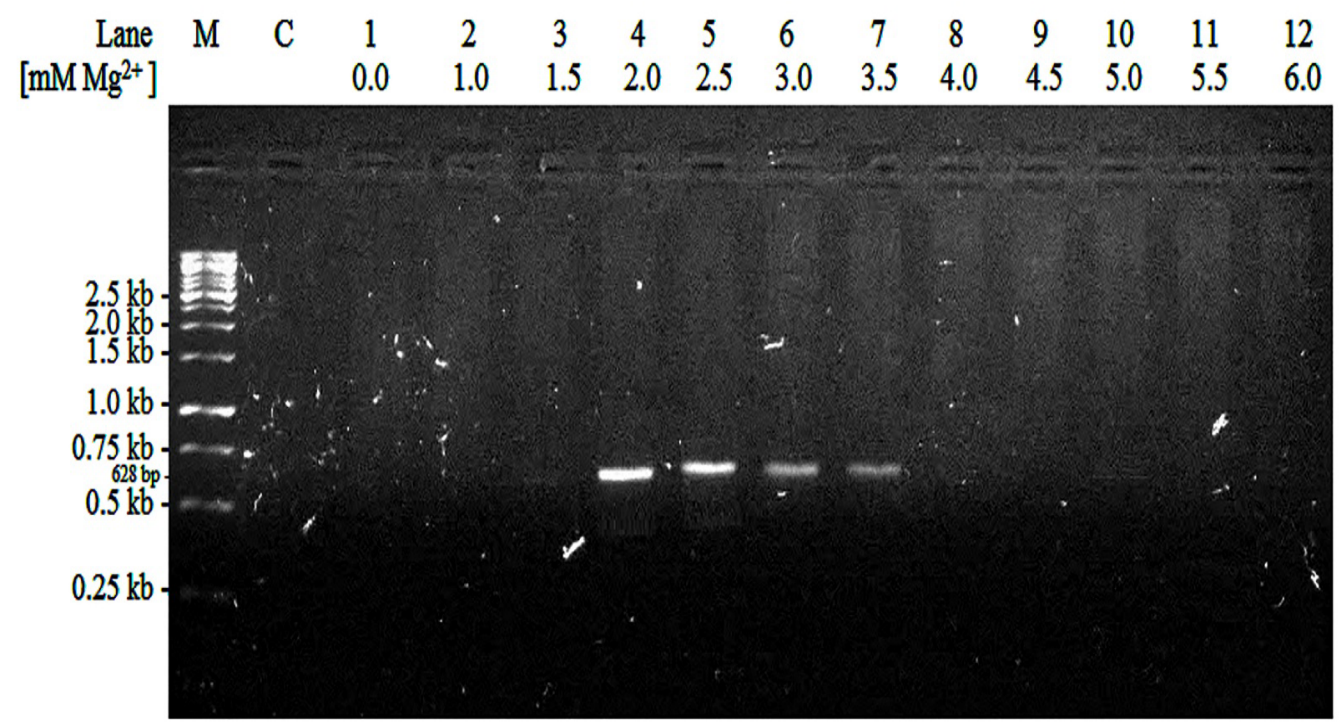

काrmm

Figure 4. The effect of $\mathrm{Mg}^{2+}$ concentrations on amplification reaction, genomic DNA extracted from blood samples $(25 \mathrm{ng} / \mu \mathrm{L})$ used as a template for amplification of the $628 \mathrm{bp}$ segment of the MITF gene

Lanes 1 to 3 show the presence of no PCR products due to low $\mathrm{Mg}^{2+}$ concentration. Lane 4 to 7 shows the presence of amplicon of the desired length with optimal $\mathrm{Mg}^{2+}$ concentrations. Lane 8 to 12 show no PCR products due to inhibition by high $\mathrm{Mg}^{2+}$ concentration. Lane (M) contains a DNA ladder. Lane (C) contains the negative control. Manufactures' recommendation for optimal $\mathrm{Mg}^{2+}$ concentrations were $1.5-2.5 \mathrm{mM}$.

\section{Non-specific binding}

There are several reasons for the non-specific binding of primers. They include repetitive sequences in the targeted DNA template, high or low GC content in the template, or incomplete primer binding, leaving the 5' end of the primer free from the template [18]. Degenerate primers are also responsible for non-specific binding. The following steps can be taken to prevent non-specific binding:

- Decreasing the primer concentration;

- Reducing the annealing temperature;

- Designing new primers.

\section{Hairpin structures}

DNA hairpins or loops also stated as secondary structures can be formed within the DNA due to high GC content. These secondary structures can stop the normal read through polymerase reaction that leads to hasty sequencing stops. Self-annealing of primer also leads to the formation of a secondary hairpin loop structure [19]. The following steps can be taken to prevent the formation of hairpin loop structures:

- Design new primers using IDT software.
- Perform NCBI primer BLAST to check primer specificity.

- Check the GC content of the designed primers.

Possible troubleshooting strategies

Autoclaved tips and tubes

General materials used in a PCR setup include Eppendorf tubes and micropipette tips. This equipment generally comes in plastic bags or containers and may or may not be in a sterilized condition. Sterilized and contamination-free consumables are essential for a successful PCR experiment. When tubes and tips are not sterilized, treat them by autoclaving at $121^{\circ} \mathrm{C}$ for $15-20$ minutes before use. Figure 3 shows the result of the PCR experiment after using unsterilized and sterilized material, including Eppendorf tubes and micropipette tips.

\section{Reagent concentrations}

One of the most important steps in achieving an optimized PCR experiment is adding reagents accordingly in the required concentrations. It is crucial to understand the role and function of each reagent to add the correct amount to the reaction mixture. Changing the concentration of $\mathrm{MgCl}_{2}$, reaction buffer, dNTPs, Taq DNA polymerase, and template DNA is an easy and reliable way to obtain optimized PCR products. However, it should 
(A)

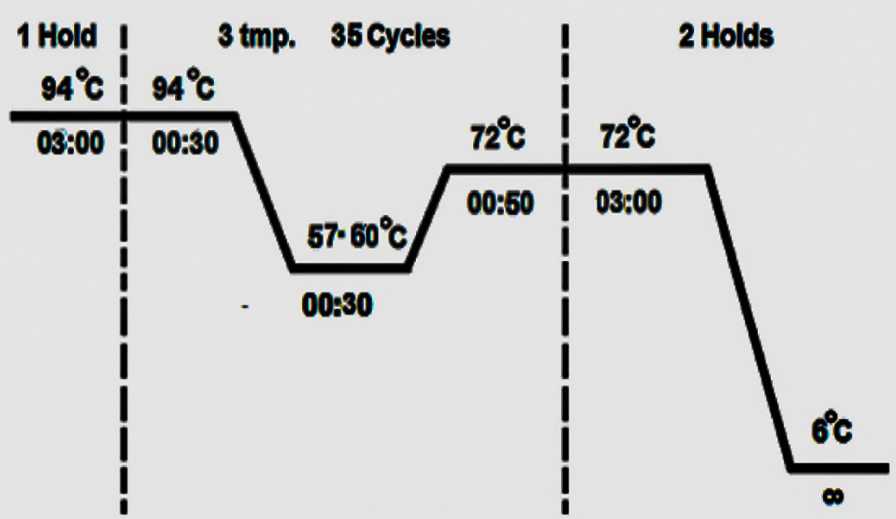

(B)

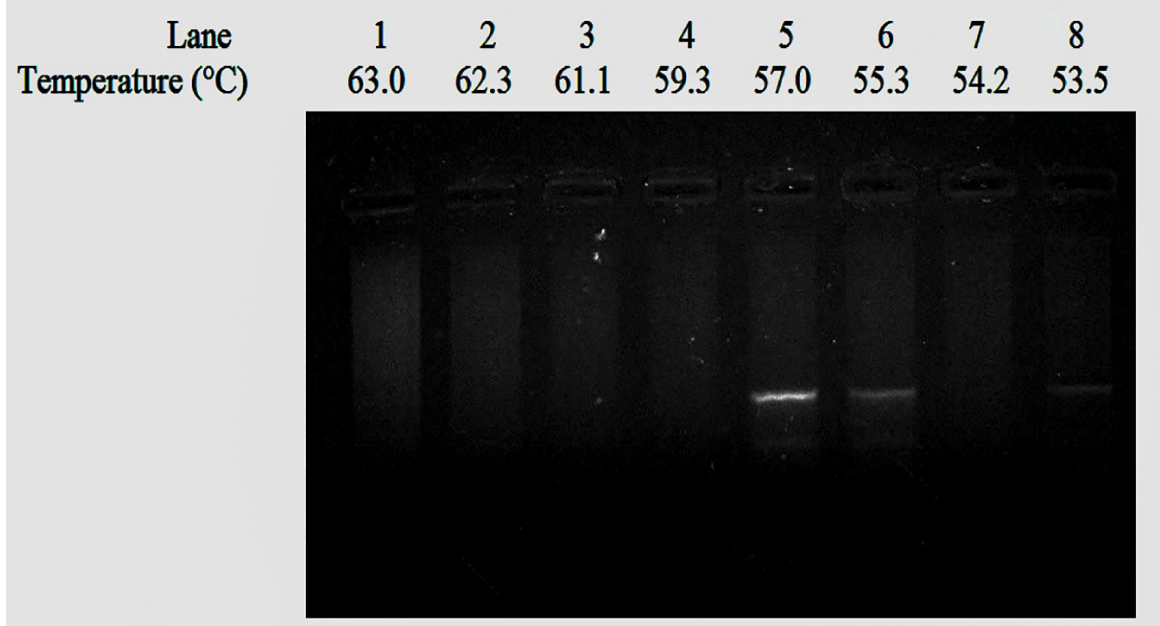

Brmm

Figure 5. Determination of optimized cycling condition

A: Graphical representation of 3-step cycling conditions used in optimization experiments; B: G-PCR to determine optimum annealing temperature for the MITF gene primers. Lanes 1 to 4 and 7 show no band formation. Lanes 5, 6, and 8 show the result of the amplification reaction. The annealing temperature of $57.0^{\circ} \mathrm{C}$ was selected based upon gradient PCR results for primers used to amplify the 628 bp segment of the MITF gene.

be considered that the addition of reagents in an incorrect concentration may result in the production of undesired amplicons of variable sizes.

\section{Template DNA}

For optimizing a PCR reaction, the first step is to add an equal concentration of DNA template to each reaction tube containing the master mix. After accomplishing this step, the remaining reagent concentrations can be altered to attain the desired PCR product. For an optimized reaction, genomic DNA concentration should be around $10-30 \mathrm{ng} / \mu \mathrm{L}$. For example, if DNA concentration is 25 $\mathrm{ng} / \mu \mathrm{L}$, then adding $2 \mu \mathrm{L}$ of the template to each reaction tube will lead to $50 \mathrm{ng}$ of DNA template in each tube. Increasing template DNA in reaction mixture should only be done if faint or weak bands are seen in AGE; otherwise, DNA overload will result in smear formation and production of non-specific amplicon resulting in a decrease in reaction specificity. Apart from the concentration of DNA, the quality influences the outcome of the PCR experiment [20].

DNA extraction protocols require the use of several solutions which may contain $\mathrm{NaCl}$, proteinase $\mathrm{K}$, phenol, EDTA, ethanol, or other solvents. The presence of extraction components in the PCR reaction mixture may inhibit the reaction or decrease reaction specificity. DNA quality can be assessed by viewing AGE bands in Image $\mathbf{J}$ software or measuring Optical Density (OD) by spectrophotometric analysis. The ratio of readings taken at $260 \mathrm{~nm}$ and $280 \mathrm{~nm}$ wavelengths indicate the purity of 


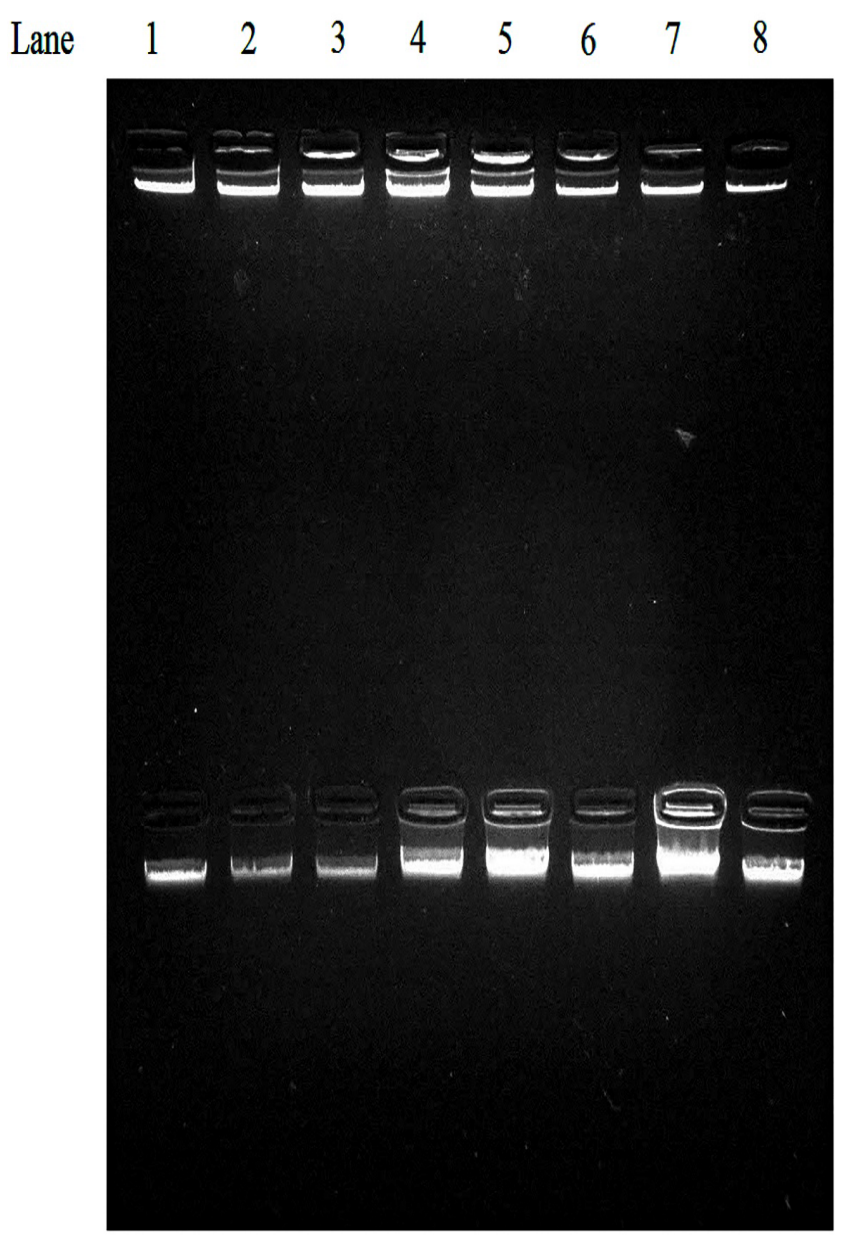

Figure 6. DNA extraction results using agarose gel electrophoresis

$1 \mathrm{~mL}$ whole blood used for extraction by an inorganic method.

the nucleic acid. DNA quality measurement based upon absorbance (A) at $260 \mathrm{~nm}$ is twice that at $280 \mathrm{~nm}$ if the solution contains pure DNA. If there is a contaminant like protein, some additional OD decreases the absorbance ratio between 260 and $280 \mathrm{~nm}$. Pure nucleic acid samples with no contamination would have an $\mathrm{A}_{260} / \mathrm{A}_{280}$ ratio of 1.8. Ratios less than these indicate contamination with protein or some other solvent. Therefore, it is required to add DNA concentration after making dilutions to ensure the quality and quantity of the DNA template.

\section{$\mathrm{MgCl}_{2}$}

Magnesium chloride acts as a co-factor for the elongation of template carried out by Taq DNA polymerase. Most failed PCR experiments can be optimized by simply changing the $\mathrm{MgCl}_{2}$ concentration in the reaction mixture. $\mathrm{MgCl}_{2}$ also interacts with other components in the reaction mixture like DNA template, dNTPs, and may increase the melting temperature by increasing DNA sta- bility. Low $\mathrm{Mg}^{2+}$ concentration may fail PCR reaction or result in incomplete amplification, whereas high $\mathrm{Mg}^{2+}$ concentration may lead to DNA strand stability, preventing annealing of primers to a template, resulting in reaction failure or the amplification of non-specific products. Figure 4 indicates the result of various $\mathrm{Mg}^{2+}$ concentrations on amplification reactions. Concentrations used in titration experiments have been provided in Table 4. $\mathrm{MgCl}_{2}$ is usually present in the $10 \mathrm{X}$ PCR reaction buffer or may be provided separately in a concentration ranging from $15 \mathrm{mM}$ to $25 \mathrm{mM}$. Concentrations may vary with the manufacturer.

\section{Reaction buffer}

The purpose of the reaction buffer is to provide optimal conditions for the reaction by maintaining the $\mathrm{PH}$ of the solution. The PCR buffer or reaction buffer may contain tris-HCL, $\left(\mathrm{NH}_{4}\right) 2 \mathrm{SO}_{4}, \mathrm{BSA}$, Triton-X, or Tween 20. Some buffers have $\mathrm{MgCl}_{2}$; otherwise, a separate 

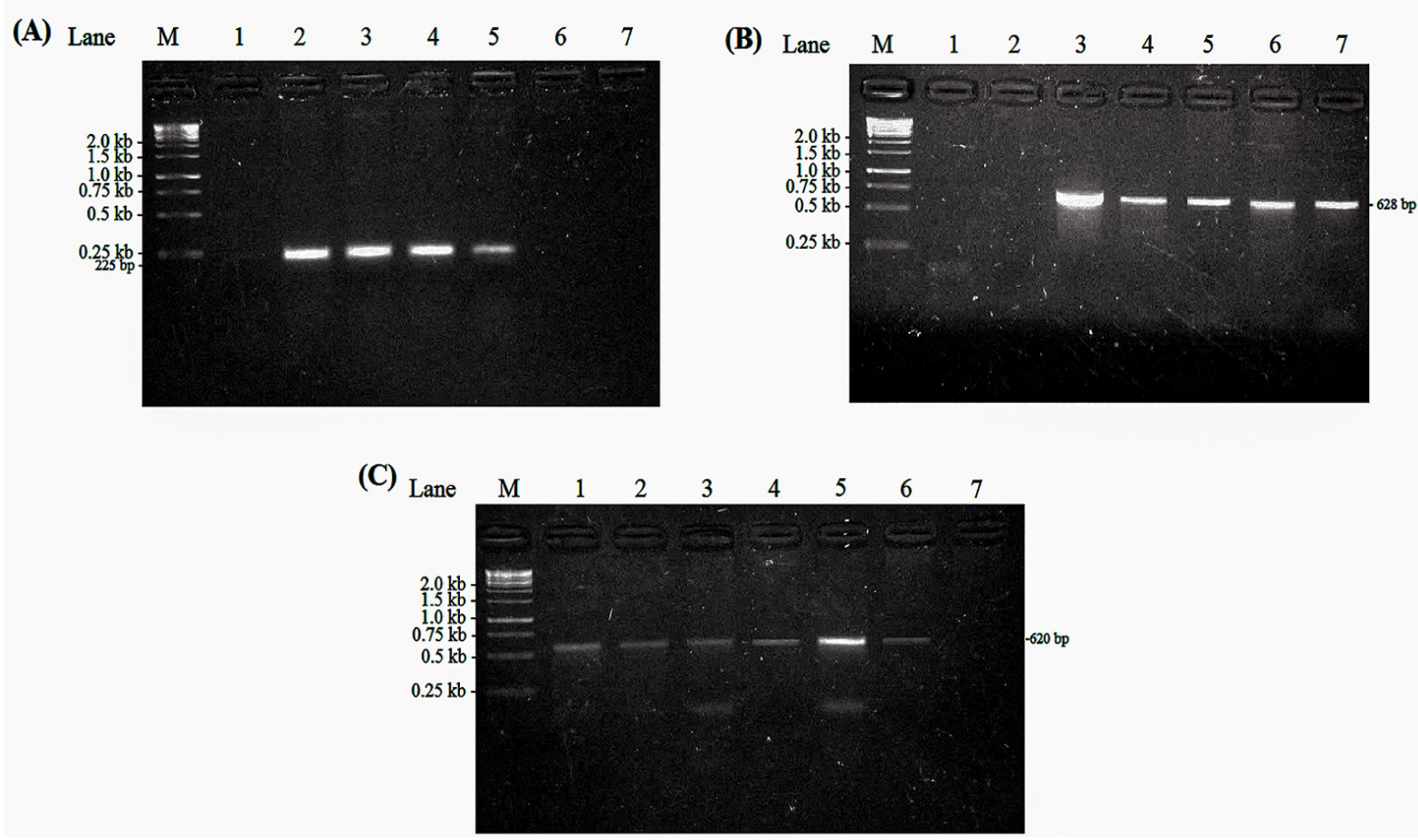

Figure 7. Optimized results based on troubleshooting strategies

DNA used in experiments extracted from whole blood samples using the inorganic method, Mg2+ and DNA concentration used 2.5 $\mathrm{mM}$ and $25 \mathrm{ng} / \mu \mathrm{L}$, respectively: A: Amplification of $225 \mathrm{bp}$ segment of the TYR gene, Lane 1 (negative control), Lanes 2 to 5 amplicons of the desired sizes, Lanes 6 and 7 (empty wells); B: Amplification of 628 bp segment of the MITF gene, Lane 1 (negative control), Lane 2 (empty well), Lanes 3 to 7 showing amplicons of the desired Size; C: Amplification of 620 bp segment of the SOX10 gene. Lanes 1 to 6 show the amplicons of the desired size. Lane 7 is the negative control. The amplicon in lane 5 shows a bright band as compared to others showing light bands. Lane (M) contains a DNA ladder in all experiments.

$\mathrm{MgCl}_{2}$ solution is usually provided. The concentrations and components of the reaction buffer may vary depending on the manufacturer [21]. Changing reaction buffer concentration can help optimize a PCR experiment. The buffer aids in polymerase activity during amplification thus, increasing reaction specificity.

\section{dNTPs}

Deoxyribonucleosides 5'- Triphosphates (dNTPs) act as a substrate for DNA polymerase involved in amplifying targeted DNA sequences. dNTPs may be in a homogenous mixture or provided separately, ranging in concentration from $20 \mathrm{mM}$ to $200 \mathrm{mM}$. dNTPs should be added in equal quantity; otherwise, the presence of one dNTP in the higher ratio may result in the incorporation of the wrong base in the newly synthesized DNA strand. For optimizing a PCR reaction, dNTPs concentrations should be increased in parallel with the $\mathrm{MgCl}_{2}$ concentration.

\section{DNA polymerase}

Polymerase is the most crucial component of the PCR experiment. Taq DNA polymerase is involved in the amplification of template DNA. The enzyme incorporates dNTPs during elongation into the newly synthesized DNA strand [22]. The polymerase may be present in variable quantities ranging from 2 to $5 \mathrm{U}$. The final concentration of DNA polymerase in the reaction mixture should be in the range of 0.02 to $0.05 \mathrm{U} / \mu \mathrm{L}$. Care should be taken while increasing polymerase concentration to achieve optimization, as this may result in smear formation due to non-specific amplification by DNA polymerase [23].

\section{Changing cycling conditions}

Besides the reagents and procedures involved in PCR, the use of appropriate cycling conditions is crucial for the optimization and success of an amplification reaction. Cycling conditions may vary from reaction to reaction based upon template size, GC content, stringency, and primer length. Table 3 indicates the basic 3-step 


\section{(A)}

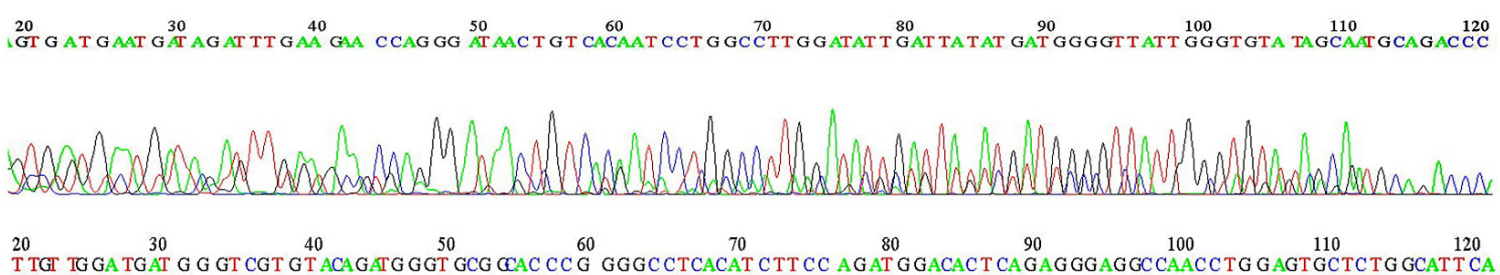

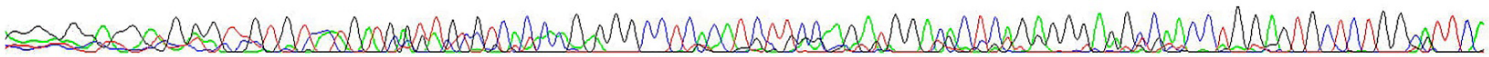

\section{(B)}

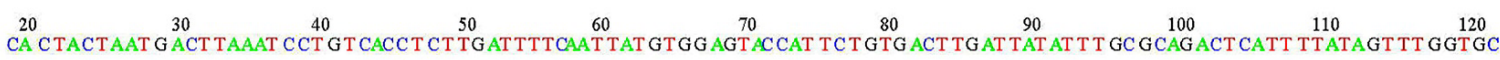

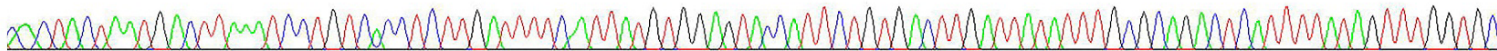

20
OCT G A GGT G ACCAT G GAAGTTCAC G T GC GC CCACC T GCCTC TAACCT GCT TCCCCCT TGC GCTC TCTCTCTCT GTCTCCCT TCTACCCAG GC CAG AGC CAT GG

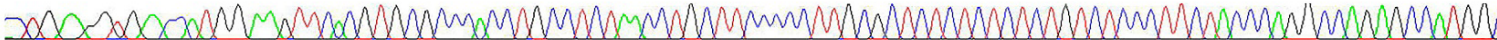

Figure 8. Comparing between sanger sequencing results of generated amplicons

A: Chromatograms showing excess background noise in amplicons not subjected to optimization; B: Chromatograms showing no background noise in amplicons generated via use of optimization strategies.

cycling condition parameters recommended while setting up a PCR experiment. Occasionally, normal cycling conditions do not work for a PCR setup; in such cases, modified cycling conditions must be used to achieve optimization [24]. Following are some versatile PCR modifications typically applied for optimization purposes.

\section{Gradient PCR (G-PCR)}

The first step in optimizing cycling conditions is to identify the $T_{a}$ of the primers. This objective can be achieved by performing a gradient PCR experiment. In this process, the annealing step in the thermal cycler is set to different temperatures. The thermal cycler is set to a range of temperatures, specific to each row; this can help determine the optimal $\mathrm{T}_{\mathrm{a}}$ for primers by checking the annealing ability of primers at various temperatures. G-PCR is a critical optimization step that can lead to successful PCR experiments. Figure 5-B designates the result of the G-PCR experiment carried out to determine the $T_{a}$ of primers used for amplification of the $628 \mathrm{bp}$ segment of the MITF gene. Each row carrying the PCR tube is subjected to a different temperature to determine the temperature most suitable for the annealing step.

\section{Touch Down PCR (TD-PCR)}

Similar to G-PCR which is used to find the optimal $\mathrm{T}_{\mathrm{a}}$ for primers, TD-PCR is a cycling modification to find suitable $\mathrm{T}_{\mathrm{a}}$. It helps prevent non-specific amplification. TD-PCR involves lowering the annealing temperature after each second cycle by $1{ }^{\circ} \mathrm{C}$ starting from $10^{\circ} \mathrm{C}$ above the calculated melting temperature and ending at $5^{\circ} \mathrm{C}$ below the calculated value. The primers will be subjected to both high and low temperatures during the cycles. This process will indicate which temperature is most suitable for the amplification reaction by exposure to high and low temperatures [25]. TD-PCR thus contributes to increasing the efficiency and specificity of the reaction

\section{Nested PCR (N-PCR)}

N-PCR is used for preventing the formation of false amplicons resulting due to non-specific binding of primers to the template strand. The principle behind N-PCR involves using two separate sets of primers during two different 3- step cycling conditions. This procedure increases the amplification of the desired targeted sequence by preventing primers from binding to unexpected locations. During the first reaction, PCR is carried out for 25- 35 cycles using one set of primers. After completing 
Table 3. PCR reaction cycling conditions

\begin{tabular}{cccc}
\hline Steps & Cycles & Time & Temperature $\left({ }^{\circ} \mathrm{C}\right)$ \\
\hline Initial denaturation & $1 \mathrm{x}$ & $03-05 \mathrm{~min}$ & $94-96$ \\
\hline Denaturation & & $15-30 \mathrm{sec}$ & 95 \\
\hline Annealing & $25-35 \mathrm{x}$ & $30-60 \mathrm{sec}$ & $54-66$ \\
\hline Elongation & & $50 \mathrm{~s}-5 \mathrm{~min}$ & $72-78$ \\
\hline Final elongation & $1 \mathrm{x}$ & $3-10 \mathrm{~min}$ & $72-78$ \\
\hline Hold"* & & $20-25$ \\
\hline
\end{tabular}

*Elongation time should be calculated based upon $\sim 1 \mathrm{~min} / 1 \mathrm{~kb}$; **Final holding temperature should be in the range of $20^{\circ} \mathrm{C}-25^{\circ} \mathrm{C}$; many thermal cyclers pause at $4^{\circ} \mathrm{C}$ after cycles have completed; this may eventually result in damage to thermal cycler by the formation of ice crystals.

the first reaction, an aliquot, usually $5-10 \mu \mathrm{L}$, is taken from the first reaction and is incorporated as a template for the second PCR reaction using a second set of primers, again for 25-35 cycles. The second set of primers usually anneal to an internal location on the template. This is useful while dealing with difficult templates with a low-copy number [26].

\section{Hot Start PCR (HS-PCR)}

HS-PCR is a relatively simple and effective modification to normal cycling conditions. The principle behind HS-PCR is to provide an increased denaturation time before the start of the general 3- step cycling setup. HSPCR modification can be used separately or also with a conventional PCR experiment. Because of a relatively high melting temperature, the amplification reaction may require optimization. HS-PCR has been proven to be an effective optimization strategy while dealing with complex templates, dimer formation, and non-specific binding if changing reagent concentrations and using sterilized equipment does not work.

The principle behind HS-PCR involves providing increased initial denaturation temperature $\left(50-90^{\circ} \mathrm{C}\right)$ for 5-10 minutes to each reaction tube containing the master mix. However, Taq DNA polymerase is withheld from the reaction mixture during this initial denaturation stage as this may inactivate the enzyme [27]. After increasing the initial temperature, the polymerase is added to each PCR tube, and the conventional three-phase setup is continued. This process helps complete denaturation of template, reduces non-specific amplification, and increases the specificity of the amplification reaction.

\section{Aliquots}

An aliquot is a portion or small part of any solution or mixture. A major cause of the PCR experiment failure is contamination. The contamination maybe dust particles, aerosols, residual chemicals, unsterilized tips, tubes, etc. To prevent contamination of reagents and chemicals used, it is always important to prepare aliquots of the original stock solutions. Thus, if contamination occurs in the working solutions, the original stock solutions will be protected from contamination and new working solutions can be prepared. Care must be taken while preparing master mix solutions as it contains all the essential components required for a successful PCR experiment. Contamination while making a reaction mixture will lead to the failure of the experiment. Always wear personal protection equipment (gloves, goggles, lab coat)

Table 4. $\mathrm{Mg}^{2+}$ titrations used in reaction mixture prepared according to Table 2 for each tube

\begin{tabular}{ccccccccccccc}
\hline Lane & $\mathbf{1}$ & $\mathbf{2}$ & $\mathbf{3}$ & $\mathbf{4}$ & $\mathbf{5}$ & $\mathbf{6}$ & $\mathbf{7}$ & $\mathbf{8}$ & $\mathbf{9}$ & $\mathbf{1 0}$ & $\mathbf{1 1}$ & $\mathbf{1 2}$ \\
\hline $\mathrm{Mg}^{2+}(\mathrm{mM})$ & 0 & 1.0 & 1.5 & 2.0 & 2.5 & 3.0 & 3.5 & 4.0 & 4.5 & 5.0 & 5.5 & 6.0 \\
$\mathrm{MgCl}_{2}(\mu \mathrm{L})$ & 0 & 0.8 & 1.2 & 1.6 & 2.0 & 2.4 & 2.8 & 3.2 & 3.6 & 4.0 & 4.4 & 4.8 \\
$\mathrm{PCR} \mathrm{H}_{2} \mathrm{O}(\mu \mathrm{L})$ & 15.4 & 14.6 & 14.2 & 13.8 & 13.4 & 13.0 & 12.8 & 12.2 & 11.8 & 11.4 & 11.0 & 10.8 \\
\hline
\end{tabular}

$\mathrm{MgCl}_{2}$ was excluded from the master mix and added separately. The final volume of each reaction tube was maintained at $20 \mu \mathrm{L}$ by titration with $\mathrm{PCR} \mathrm{H}_{2} \mathrm{O}$. 
Table 5. Agarose gel composition

\begin{tabular}{cl}
\hline Gel Components & Quantity \\
\hline Agarose powder & $0.9 \mathrm{gm}^{*}$ \\
\hline TBE buffer & $60 \mathrm{~mL}$ \\
\hline $\mathrm{EtBr}$ & $3 \mu \mathrm{L}$ \\
\hline DNA sample & $5 \mu \mathrm{L}$ \\
\hline Loading Dye & $2 \mu \mathrm{L}$ \\
\hline &
\end{tabular}

*1.5\% agarose gel slab was prepared. To make a gel slab of different concentration, change the values up to the required mark.

while handling reagents and preparing master mix to prevent contamination.

\section{Additives}

If the PCR experiment fails even after changing cycling conditions and manipulating reagent concentrations, it is time to add some additional components to the reaction mixture to aid the amplification reaction. Following are some additives, which can be added to increase reaction efficiency and specificity.

\section{Dimethyl Sulfoxide (DMSO)}

It is an organosulfur compound that dissolves both nonpolar and polar compounds and acts as a denaturant. It is generally used as an additive reagent in PCR experiments that contain high GC-rich templates. DMSO acts as a reaction enhancer by lowering $\mathrm{T}_{\mathrm{m}}$ and reducing the secondary structure [28]. DMSO may be added to the reaction mixture according to the requirement ranging in concentrations from $1 \%$ to $10 \%$.

\section{Bovine Serum Albumin (BSA)}

Reaction failure may occur due to the presence of inhibitors in the PCR tube. These inhibitors may be present due to contamination, residual chemicals left from the extraction procedures, or constituents of tissue, blood, saliva samples used in DNA extraction [29]. BSA is a serum albumin protein and used in PCR reactions to counter the effect of inhibitors and prevent the inactivation of DNA polymerase. BSA should be used in concentrations from 0.1 to $1.0 \mathrm{mg} / \mathrm{mL}$.

\section{Betaine}

Betaine is classified as a type of zwitterion and is widely used in PCR reactions for optimization. Betaine helps in amplification reaction by reducing the secondary structures formed because of high GC-rich templates $(>60 \%)$ and may also reduce $\mathrm{T}_{\mathrm{m}}$ to increase reaction specificity [28]. Betaine should be added in concentration from $1.0 \mathrm{M}$ to $2.0 \mathrm{M}$.

\section{Formamide}

It is an amide derived from formic acid. Just like betaine, formamide acts as an enhancer for GC- rich templates. It also helps in the annealing of primers to the template strand and reduces $\mathrm{T}_{\mathrm{m}}$. Formamide should be added to the reaction mixture in concentrations from $1 \%$ to $10 \%$.

\section{Glycerol}

It is classified as a polyol compound. Glycerol acts as a stabilizing agent for DNA polymerase and improves reaction efficiency by preventing the formation of secondary structures due to high GC- rich templates. Glycerol should be added for optimizing reactions in concentration from $1 \%$ to $10 \%$.

\section{Triton- $X$ and tween 20}

Both Triton-X and Tween 20 are detergents and used in PCR for preventing the formation of secondary structures and, act as stabilizing agents for DNA polymerase. Separate solutions maybe present for each additive. Both reagents should be used in a concentration ranging from $0.1 \%$ to $1 \%$. Increased detergent concentration may lead to inhibition of polymerase reaction [30].

It is to be noted that some manufactures include a solution ' $\mathrm{S}$ ' with reagents provided containing additives in a definite ratio to be used for optimizing failed PCR experiments for GC-rich templates or non-specific amplification. The additive solution should be added in a concentration of $1 \mathrm{X}, 2 \mathrm{X}$ or $3 \mathrm{X}$. 


\section{Organized procedure}

While addressing the trouble shooting strategies for optimizing PCR, it is crucial to remove any handling error which may result in a failed experiment. One of the most important considerations with regard to a successful PCR experiment is the removal of distractions from the work environment. These guidelines should be followed to help obtain desired results:

- Arrange all reagents and chemical in a precise order before the start of the procedure.

- Remove any unwanted materials and equipment from the workspace.

- Clean the workbench and micropipettes with $70 \%$ ethanol and tissue paper.

- Make a list of reagents in the proper order to be added to each reaction tube.

- Mark $(\checkmark)$ each reagent that has been added.

- Close the PCR tube after adding each reagent.

- Double-check the reagent list after adding any chemical.

- Do not let micropipette, tips and PCR tube touch the work bench as this may lead to contamination.

- For ease and convenience, you may seek the help of any lab assistant to set up a PCR reaction.

The present study demonstrates a novel approach using low-cost, kit-free optimization strategies to produce amplicons of desired size and intensity. Sequence analysis was performed to confirm the synthesis of amplicons via optimization strategies. Currently, there is no evidence of PCR troubleshooting protocol with results validated by the sequencing approach.

\section{Materials and Methods}

\section{Sample collection}

Blood samples were taken from participants involved in this study. Informed written consent was taken from each participant before taking blood samples. Clean $5 \mathrm{~mL}$ sterile syringes were used to extract $1.5-3 \mathrm{~mL}$ blood samples from each participant. The extracted blood samples were placed in 5mL EDTA tubes (BD, USA). These blood samples were stored at $4^{\circ} \mathrm{C}$ during transportation to the research facility. However, blood samples were frozen at $-20^{\circ} \mathrm{C}$ in the laboratory until used for DNA extraction.

\section{DNA isolation}

Genomic DNA as a template for amplification experiments was extracted from whole blood samples using the salting-out (in-organic) method (https://www.researchgate.net/publication/323878803_DNA_Extraction_Protocol_1). The protocol was optimized for extraction with a $1 \mathrm{~mL}$ of the whole blood sample. Before the start of the extraction procedure, all blood samples were thawed and left for 30 minutes. All steps were carried out at room temperature. Buffers and solutions $(\mathrm{PH}$ 8.0) were stored at room temperature and capped tightly to prevent contamination. Before use, isopropanol was chilled at $-4^{\circ} \mathrm{C}$ for 3 hours. Proteinase $\mathrm{K}$ was kept refrigerated until used. After extraction, DNA samples were transferred into $1.5 \mathrm{~mL}$ Eppendorf tubes (Axygen, USA) for storage at $-4^{\circ} \mathrm{C}$ before use.

\section{Quantification of extracted DNA samples}

The extracted DNA samples were quantified using AGE and spectrophotometry (OD) analysis. Quantification via AGE involves the use of UV-induced fluorescence of $\mathrm{EtBr}$ dye, intercalated into the nucleic acid. The amount of fluorescence produced is proportional to the concentration of nucleic acid present. Fluorescence of the sample DNA and that of a standard DNA was compared. Also, a 1.5\% agarose gel slab (stained with $3 \mu \mathrm{l} \mathrm{EtBr}$ ) was prepared (Table 5) (see the section on Equipment and Chemicals). The gel was loaded by $5 \mu \mathrm{L}$ of each DNA sample mixed with $2 \mu \mathrm{L}$ of loading dye (Bromophenol blue 2X) and was run on $120 \mathrm{~V}$ for 35 minutes on a Horizontal AGE system (Cleaver Scientific, UK). The gel slab was observed in gel documentation apparatus Dolphin-Doc Plus (Wealtec Corp, USA) using Dolphin-1D Gel Analysis Software.

Figure 6 shows the results of genomic DNA extraction using AGE. Concentrations and quality of extracted DNA samples were determined by measuring the OD at 260 and $280 \mathrm{~nm}$ wavelengths using a NanoDrop ${ }^{\mathrm{TM}}$ spectrophotometer (Thermo Fisher Scientific, USA; see the section on Template DNA). The concentrations of DNA samples ranged from 57.6 to $125.0 \mathrm{ng} / \mu \mathrm{L}$. The OD values of extracted DNA samples fell in the range of 1.58 to 1.74 . The concentration and quantity of DNA samples were recorded in DNA extraction sheets. All DNA samples were stored in the repository at $-20^{\circ} \mathrm{C}$ until further use. 


\section{Designing of sequencing primers}

For the optimization experiments, the separate sets of primers were designed for TYR (OMIM\# 606933), MITF (OMIM\# 156845), and SOX10 (OMIM\# 602229) human genes. Exon sequences for the candidate genes were taken from Ensemble genome browser entries (https://www.ensembl.org/Homo_sapiens/Info/Index) of ENSG00000077498, ENSG00000187098, and ENSG00000100146. Primers were designed using the Primer3 web server (https://primer3.ut.ee/) based on the parameters discussed previously (see the section on 'Primer Designing'). The number of bases in each primer ranged from 18 to 21 bases. GC content of each primer fell in the range of $50 \%$ to $60 \%$. The calculated $\mathrm{T}_{\mathrm{m}}$ of each primer was between $56^{\circ} \mathrm{C}$ to $60^{\circ} \mathrm{C}$. The virtual specificity and $\mathrm{T}_{\mathrm{m}}$ of the designed primers against the human genome were determined by using NCBI Primer-BLAST search (https://www.ncbi.nlm.nih.gov/ tools/primer-blast/) and UCSC insilico PCR analysis (https:/genome.ucsc.edu/cgi-bin/hgPcr). Finally, the selected primer sequences were sent to Macrogen (Seoul, South Korea) for synthesis.

Determining cycling conditions for PCR amplification

Standard 3-step PCR cycling conditions were used for the optimization experiment. Cycling conditions were determined based upon parameters discussed in Table 3 (see section on cycling conditions). G-PCR experiments were performed for determining $T_{a}$ for each primer sets used for amplification of each of the specific candidate gene (Figure 5-B). The initial denaturation was performed at $94^{\circ} \mathrm{C}$ for $3 \mathrm{~min}$, followed by 35 cycles of denaturation at $94^{\circ} \mathrm{C}$ for 30 seconds. Annealing temperature differed for each set of primers and was provided for 30 seconds, followed by extension at $72^{\circ} \mathrm{C}$ for 50 seconds. The final elongation step was carried out at $72^{\circ} \mathrm{C}$ for 3 minutes. After the completion of PCR cycles, the samples were kept at a holding temperature of $6^{\circ} \mathrm{C}$. PCR amplicons were stored at $4^{\circ} \mathrm{C}$ before use in AGE analysis. Graphical representation of cycling conditions used is indicated in Figure 5-A.

\section{Reagent concentrations}

The concentration of chemicals and reagents used in optimization experiments are described in Table 1. Master mix solution $\left(2.5 \mathrm{mM} \mathrm{MgCl}_{2}, 0.2 \mathrm{mM}\right.$ dNTPs, $0.24 \mathrm{U} \mathrm{Taq}$ DNA polymerase, 1X PCR Reaction buffer) was prepared before the experiment (see section on "Master Mix Preparation"). $\mathrm{Mg}^{2+}$ concentrations required for optimization experiments were selected based on titration results (Fig- ure 4). The optimization experiments involved using various DNA samples and different primers $(10 \mu \mathrm{M})$ for each selected candidate gene. All reagents used in optimization experiments were purchased from Solis BioDyne (Tartu, Estonia). For a detailed procedure on reaction setup, see the section on "Step by Step Protocol".

\section{PCR amplification}

Optimization experiments to generate amplicons were carried out in $0.2 \mathrm{~mL}$ PCR tubes (Axygen, USA). The final PCR tube volume consisted of a $20 \mu \mathrm{L}$ total reaction mixture (Table 2). PCR amplification was performed in Bio$\operatorname{Rad} \mathrm{T} 100^{\mathrm{TM}}$ thermal cycler (Bio-Rad Laboratories, USA). Amplicons were visualized using AGE on a 1.5\% gel slab stained with EtBr dye. GeneRuler ${ }^{\mathrm{TM}} 1 \mathrm{~Kb}$ DNA Ladder (Thermo Fisher Scientific, USA) was used as a standard tool for comparing the sizes of amplicons generated.

\section{Purification of PCR products}

Before sequencing, the excess primers and dNTPs must be removed from the PCR products. For this purpose, ExoSAP (exonuclease-I and shrimp alkaline phosphatase) was performed. Exonuclease-I is involved in the degradation of unutilized primers into monophosphates, whereas shrimp alkaline phosphatase catalyzes the release of phosphate groups from excess dNTPs. Also, 2 $\mu \mathrm{L}$ of ExoSAP was added to $5 \mu \mathrm{L}$ of each PCR product. The final reaction volume was maintained up to $1 \mathrm{~mL}$. The samples were then incubated at $37^{\circ} \mathrm{C}$ for 30 minutes. After the incubation, step samples were exposed to $95^{\circ} \mathrm{C}$ for 5 minutes to deactivate the exonuclease-I enzyme.

\section{Sequencing analysis}

To determine the specificity and quality of the PCR amplification by applying the optimization strategies, direct sequence analysis was performed. Amplicons generated with and without the aid of optimization strategies for MITF and SOX10 genes were sequenced using ABI 3730 DNA Analyzer (Thermo Fisher Scientific, USA). Chromatograms were visualized using Chromas Lite software (http://technelysium.com.au/wp/chromas/). Sequence comparison and alignment of the obtained sequences with that of the reference sequence of MITF (GenBank reference: NG_011631.1) and SOX10 (GenBank reference: NG_007948.1) genes was made using NCBI-nucleotide BLAST (https://blast.ncbi.nlm.nih. gov/Blast.cgi). Sequence data analysis was performed using CLC sequence viewer (https://www.qiagenbioinformatics.com/products/clc-sequence-viewer/). 


\section{Results}

The amplicons generated are based upon the optimization strategies and protocols as discussed in the previous section. Following the procedures mentioned above and troubleshooting approaches, optimized PCR products were obtained without using PCR kits. The optimization experiment involved the amplification of segments of $T Y R, M I T F$, and SOX10 human genes. The $\mathrm{T}_{\mathrm{a}}$ of each primer set was determined separately by the G-PCR method (Figure 5). Eight different annealing temperatures ranging from $53.5^{\circ} \mathrm{C}$ to $63^{\circ} \mathrm{C}$ were tested for each primer. The $\mathrm{T}_{\mathrm{a}}$ values of primers used were determined to be $56.5^{\circ} \mathrm{C}, 57^{\circ} \mathrm{C}$, and $60^{\circ} \mathrm{C}$ for each candidate gene, respectively. Standard 3-step cycling conditions were used for the optimization experiment.

Concentrations of genomic DNA samples were determined by a NanoDrop ${ }^{\mathrm{TM}}$ spectrophotometer in $\mathrm{ng} /$ $\mu \mathrm{L}$. DNA samples differed in their initial concentrations ranging from 57.6 to $125.0 \mathrm{ng} / \mu \mathrm{L}$. Low DNA concentration results in no amplification reaction whereas, high DNA concentrations may lead to non-specific amplification due to template overload. To achieve optimized PCR products, an equal quantity of DNA samples must be added to each reaction tube. About $50 \mu \mathrm{L}$ from each initial extracted DNA sample was taken and transferred to new tubes. The aliquots were then diluted with $\mathrm{TE}$ (Tris-EDTA) buffer according to their concentrations. Final concentrations of $25 \mathrm{ng} / \mu \mathrm{L}$ were achieved for each genomic DNA sample. The reaction buffer used in reactions did not contain $\mathrm{Mg}^{2+}$, which was incorporated separately while preparing the master mix solution. Too low or high $\mathrm{Mg}^{2+}$ concentration may lead to reaction failure. Twelve different $\mathrm{Mg}^{2+}$ concentrations ranging from 0.0 to $6.0 \mathrm{mM}$ were tested to determine the required concentration. Optimum $\mathrm{Mg}^{2+}$ concentration $(2.5 \mathrm{mM}$ ) was used for optimization experiments based upon titration test results indicated in Figure 4. The fresh master mix was prepared before starting each experiment to eliminate the chance of inactivation of any reagent used (Figure 2). All Eppendorf tubes and micropipette tips used in the experiments were autoclaved at $121^{\circ} \mathrm{C}$ for $15 \mathrm{~min}$ utes to prevent contamination (Figure 4).

PCR amplification was carried out in Bio-Rad T100 ${ }^{\mathrm{TM}}$ thermal cycler (Bio-Rad Laboratories, USA). Based upon the optimization strategies, amplicons were generated by primers for the segments of TYR, MITF, and SOX10 genes. In Figure 7-A, genomic DNA extracted from whole blood samples was used to amplify the 225 bp segment of the TYR gene. The gene encodes for a copper-containing enzyme tyrosinase involved in the mela- nin biosynthesis pathway. Mutations in the $T Y R$ gene are associated with oculocutaneous albinism and ocular albinism. Lanes 2 to 5 show the amplicons of the desired size. Each well contains a different DNA sample used for the PCR experiments. Lanes 6 and 7 do not contain any samples, whereas lane 1 contains negative control.

Figure 7-B shows the results of the amplification reaction carried out to generate amplicons of the $628 \mathrm{bp}$ segment of the MITF gene. The gene encodes for the Microphthalmia-associated Transcription Factor (MITF) protein. This transcription factor is involved in the differentiation of mast cells, osteocytes, and melanocytes. $M I T F$ also acts as an activator for TYR. Mutations in the MITF gene are associated with Tietz syndrome, Waardenburg syndrome, and pigment anomalies resulting from abnormalities in melanogenesis and melanocyte differentiation. Lanes 3 to 7 show amplicons of the desired size. Separate DNA samples were used for each PCR experiment. Lane 1 shows negative control, and lane 2 does not contain any sample.

Figure 7-C shows the amplification reaction results to generate amplicons of the $620 \mathrm{bp}$ segment of the SOX10 gene. The gene encodes for the SRY-related HMG-box 10 (SOX10) transcription factor protein. This transcription factor is involved in determining cell fate and neural crest formation during embryonic development. The $M I T F$ gene has been associated with controlling the expression of the $S O X 10$ gene in melanocytes. Mutations in the SOX10 gene are associated with melanoma and Waardenburg syndrome. Lanes 1 to 6 show amplicons of the desired size, however apart from the sample in Lane 5, all other bands are faint compared with bands in Figure 7-A and Figure 7-B. This fact may indicate partial amplification and more cycle required in the PCR experiment. Lane (M) in all figures contains a DNA ladder for determining amplicon size.

The amplicon generated by optimization experiments for MITF and SOX10 genes were sequenced using ABI3730 DNA Analyzer (Thermo Fisher Scientific, USA). Sequence specificity was determined using NCBInBLAST analysis. Sequences were also aligned with reference genome sequences using a CLC sequence viewer.

Figure 8 shows the chromatogram sequences of generated amplicons. PCR products that were not subjected to optimization procedures showed initial background noise (Figure 8-A) as compared to the amplicons generated via the help of optimization strategies (Figure 8-B). 


\section{Discussion}

PCR has become an indispensable tool for researchers and diagnosticians working on various projects throughout the world. Although its widespread usage for over three decades has made it extremely popular, the procedure itself is quite complicated and requires patience to achieve success. Adequate guidance is essential for any beginner attempting to perform a PCR experiment. However, in a research lab, undergraduate researchers are usually not the focus of superiors when they require the most attention and supervision. The reagents and material required for an amplification reaction are costly, and PCR purification kits are not economical in labs with limited facilities. In low-cost setups, the optimization strategies and step-by-step guide discussed in this study can help attain desired amplification results without dealing with repeated frustrating experiments to generate desired amplicons.

In the present study, genomic DNA was extracted from blood samples using an inorganic method. The concentration and purity of extracted DNA were determined by spectrophotometric analysis. For a successful PCR reaction, the first step is adding an equal quantity of template DNA to the reaction mixture [3, 11]. For this purpose, all samples were diluted to maintain an equal concentration in the range of 20 to $30 \mathrm{ng} / \mu \mathrm{L}$ for all reaction tubes.

Before the experiments, all equipment and material used were autoclaved to prevent contamination; the use of sterilized material has been emphasized in previous protocols $[12,14,16]$ concerning optimization strategies for PCR. However, there is no evidence of the use of autoclaved materials as an optimization strategy.

Standard PCR buffer was used with the addition of dNTPs in the reaction, but $\mathrm{MgCl}_{2}$ was excluded from the reaction mixture. For the reaction conditions, $\mathrm{Mg}^{2+}$ concentration is the most crucial factor. Too high or too low $\mathrm{Mg}^{2+}$ concentration often leads to reaction failure [10, 14]. For this study, different $\mathrm{Mg}^{2+}$ concentrations were tested within the range of 0.0 to $6.0 \mathrm{mM}$. Optimum $\mathrm{Mg}^{2+}$ (2.0$3.0 \mathrm{mM}$ ) quantity required for amplification reaction was determined with titration experiments (Figure 4).

To optimize the cycling conditions used in the optimization experiments, the duration of cycles, annealing temperature, and the number of cycles should be determined $[17,23]$. The annealing temperature is an essential parameter for PCR optimization $[15,17]$ and must be adjusted to prevent non-specific binding and dimer formation. For determining the optimum annealing tem- peratures for primers used, G-PCR experiments were performed to test a range of temperatures from $53^{\circ} \mathrm{C}$ to $63^{\circ} \mathrm{C}$. The optimum annealing temperature for primers used in the study ranged from $56.5^{\circ} \mathrm{C}$ to $60^{\circ} \mathrm{C}$, which was approximately equal to the predicted value [7].

No PCR additives were used for the optimization experiments. The use of additive reagents such as betaine and DMSO $[19,20]$ depends upon high GC-rich templates, high annealing temperature, and contaminations $[29,30]$. Care must be taken while adding additives to the PCR mixture, as this may alter the reaction conditions.

The optimization strategies discussed in the article are applicable for a conventional PCR setup. Because of complexities in intricate reaction setups like multiplex PCR, RT-PCR, colony PCR, qPCR, and so on, they have been excluded from this guide. To achieve desired sequencing results for mutation analysis, genotyping, and molecular diagnostics, the first step is to produce optimized amplicons.

In Figure 7, the optimized results were not attained on the first try; repeated experiments had to be performed using the troubleshooting strategies and reviewing each parameter involved one at a time to produce desired amplicons, which were later used for Sanger sequencing. Reagent concentration, especially $\mathrm{Mg}^{2+}$ and DNA quantity, are important considerations while optimizing a PCR reaction. Similarly, optimum annealing temperature and cycling conditions also influence reaction outcome (See the section on "possible troubleshooting strategies" for detailed procedure). Sequence analysis was performed to determine the quality and specificity of amplicons generated via optimization strategies.

Usually, at the start of Sanger sequencing results, the first 50-80 bases show background noise (Figure 8-A), complicating the actual base sequence. Whereas in the case of Figure 8-B, no background noise is present in either chromatogram. Sequencing outcomes depend on the quality of amplicon used; thus, optimizing PCR experiments to attain desired amplicons is necessary for decent sequencing results. The sequencing approach for determining the effectiveness of optimization strategies has not been employed. Currently, no evidence of PCR troubleshooting protocol with results validated by the sequencing outcomes exists. Hence this report demonstrates for the first time the effectiveness of low-cost optimization strategies for amplicon generation without the aid of PCR kits with supporting evidence from sequencing analysis. The protocol and strategies described in this study are easy to perform and essential for day- 
to-day laboratory work. While troubleshooting failed procedures, one must remember to change only one parameter at a time. Knowing the function of each reaction constituent is also a critical thing is to keep on trying and be patient throughout the process.

\section{Conclusion}

PCR is a critical component in molecular biology and has been subjected to numerous improvements since its invention. With its various applications in biomedical research, molecular genetics, and forensic sciences, its replacement with an advanced and more efficient procedure is not going to happen soon. Because of its complexity and several components, PCR can be time-consuming and painstakingly difficult to perform perfectly and often leads to frustration due to repeated failures. The correct way to get optimized PCR results is to understand each reaction constituent and follow a step-by-step procedure. Following this guide, anyone lacking proper supervision and with little or no knowledge of the procedure could attain the desired results. The first step for a successful PCR is to use sterilized and contamination-free materials and reagents. Optimizing PCR amplification requires adequate $\mathrm{MgCl}_{2}$ concentration, DNA quantity, and optimum annealing temperature. PCR additives like formamide, DMSO, and betaine should only be used in a definite ratio to tackle GC-rich template regions. The most important thing while dealing with a failed experiment is to be patient and try again by evaluating each reaction component. Eventually, repeated efforts often lead to success.

\section{Ethical Considerations}

\section{Compliance with ethical guidelines}

This study was approved by the Ethics Review Committee of International Islamic University, Islamabad, Pakistan. Informed consent was obtained from all the participants before blood sampling.

\section{Funding}

This research did not receive any grant from funding agencies in the public, commercial, or non-profit sectors.

\section{Authors' contributions}

Conceptualization: Saaim Asif, Maaz Khan, and Muhammad Waqar Arshad; Methodology, writing, review, and editing: All Authors; Investigation: Saaim Asif, Maaz Khan, and Muhammad Imran Shabbir; Writing the original draft: Saaim Asif and Maaz khan; Supervision, Muhammad Imran Shabbir.

\section{Conflict of interest}

The authors declared no conflict of interest.

\section{References}

[1] Mullis KB. The unusual origin of the polymerase chain reaction. Sci Am. 1990; 262(4):56-61, 64-5. [DOI:10.1038/scientificamerican0490-56] [PMID]

[2] Kleppe K, Ohtsuka E, Kleppe R, Molineux I, Khorana HG. Studies on polynucleotides: XCVI. Repair replication of short synthetic DNA's as catalyzed by DNA polymerases. J Mol Biol. 1971; 56(2):341-61. [DOI:10.1016/0022-2836(71)90469-4]

[3] Eisenstein BI. The polymerase chain reaction: A new method of using molecular genetics for medical diagnosis. N Engl J Med. 1990; 322(3):178-83. [DOI:10.1056/ NEJM199001183220307] [PMID]

[4] Koressaar T, Remm M. Enhancements and modifications of primer design program Primer3. Bioinformatics. 2007; 23(10):1289-91. [DOI:10.1093/bioinformatics/btm091] [PMID]

[5] Dieffenbach CW, Lowe TM, Dveksler GS. General concepts for PCR primer design. PCR Methods Appl. 1993; 3(3):S30-7. [DOI:10.1101/gr.3.3.S30] [PMID]

[6] Bustin SA, Mueller R, Nolan T. Parameters for successful PCR primer design. Methods Mol Biol. 2020; 2065:5-22. [DOI:10.1007/978-1-4939-9833-3_2] [PMID]

[7] Kalendar R, Lee D, Schulman AH. Java web tools for PCR, in silico PCR, and oligonucleotide assembly and analysis. Genomics. 2011; 98(2):137-44. [DOI:10.1016/j.ygeno.2011.04.009] [PMID]

[8] Rychlik W, Spencer WJ, Rhoads RE. Optimization of the annealing temperature for DNA amplification in vitro. Nucleic Acids Res. 1990; 18(21):6409-12. [DOI:10.1093/ nar/18.21.6409] [PMID] [PMCID]

[9] Henke W, Herdel K, Jung K, Schnorr D, Loening SA. Betaine improves the PCR amplification of GC-rich DNA sequences. Nucleic Acids Res. 1997; 25(19):3957-8. [DOI:10.1093/ nar/25.19.3957] [PMID] [PMCID]

[10] Roux KH. Optimization and troubleshooting in PCR. Cold Spring Harb Protoc. 2009; 2009(4):pdb.ip66. [DOI:10.1101/ pdb.ip66] [PMID]

[11] Garibyan L, Avashia N. Research techniques made simple: Polymerase chain reaction. J Invest Dermatol. 2013; 133(3):1-4. [DOI:10.1038/jid.2013.1] [PMID] [PMCID]

[12] Sahdev S, Saini S, Tiwari P, Saxena S, Singh Saini K. Amplification of GC-rich genes by following a combination strategy of primer design, enhancers and modified PCR cycle conditions. Mol Cell Probes. 2007; 21(4):303-7. [DOI:10.1016/j. mcp.2007.03.004] [PMID] 
[13] Kramer MF, Coen DM. The polymerase chain reaction Curr Protoc Protein Sci. 2002; Appendix 4:Appendix 4J. [DOI:10.1002/0471140864.psa04js29] [PMID]

[14] Lorenz TC. Polymerase chain reaction: Basic protocol plus troubleshooting and optimization strategies. J Vis Exp. 2012 (63):e3998. [DOI:10.3791/3998] [PMID] [PMCID]

[15] Brownie J, Shawcross S, Theaker J, Whitcombe D, Ferrie $\mathrm{R}$, Newton C, et al. The elimination of primer-dimer accumulation in PCR. Nucleic Acids Res. 1997; 25(16):3235-41. [DOI:10.1093/nar/25.16.3235] [PMID] [PMCID]

[16] Mullis KB. The polymerase chain reaction in an anemic mode: How to avoid cold oligodeoxyribonuclear fusion. CR Methods Appl. 1991; 1(1):1-4. [DOI:10.1101/gr.1.1.1] [PMID]

[17] Pavlov AR, Pavlova NV, Kozyavkin SA, Slesarev AI. Recent developments in the optimization of thermostable DNA polymerases for efficient applications. Trends Biotechnol. 2004 22(5):253-60. [DOI:10.1016/j.tibtech.2004.02.011] [PMID]

[18] Mendel CM, Mendel DB. 'Non-specific'binding. The problem, and a solution. Biochem J. 1985; 228(1):269-72. [DOI:10.1042/bj2280269] [PMID] [PMCID]

[19] Singh VK, Govindarajan R, Naik S, Kumar A. The effect of hairpin structure on PCR amplification efficiency. Mol Biol Today. 2000; 1(3):67-9. https://citeseerx.ist.psu.edu/view$\mathrm{doc} /$ download?doi=10.1.1.694.1031\&rep=rep1\&type=pdf

[20] Erlich HA, Gelfand D, Sninsky JJ. Recent advances in the polymerase chain reaction. Science. 1991; 252(5013):1643-51. [DOI:10.1126/science.2047872] [PMID]

[21] Blanchard MM, Taillon-Miller P, Nowotny P, Nowotny V. PCR buffer optimization with uniform temperature regimen to facilitate automation. PCR Methods Appl. 1993; 2(3):23440. [DOI:10.1101/gr.2.3.234] [PMID]

[22] Kramer MF, Coen DM. Enzymatic amplification of DNA by PCR: Standard procedures and optimization. Curr Protoc Pharmacol. 2001; Chapter 6:Unit6.7. [DOI:10.1002/0471141755.ph0607s13] [PMID]

[23] Eckert KA, Kunkel TA. DNA polymerase fidelity and the polymerase chain reaction. PCR Methods Appl. 1991; 1(1):1724. [DOI:10.1101/gr.1.1.17] [PMID]

[24] Mullis KB. Target amplification for DNA analysis by the polymerase chain reaction. Ann Biol Clin (Paris). 1990; 48(8):57982. [PMID]

[25] Green MR, Sambrook J. Touchdown polymerase chain reaction (PCR). Cold Spring Harb Protoc. 2018; 2018(5). [DOI:10.1101/pdb.prot095133] [PMID]

[26] Green MR, Sambrook J. Nested Polymerase Chain Reaction (PCR). Cold Spring Harb Protoc. 2019; 2019(2). [DOI:10.1101/ pdb.prot095182] [PMID]

[27] Green MR, Sambrook J. Hot start Polymerase Chain Reaction (PCR). Cold Spring Harb Protoc. 2018; 2018(5). [DOI:10.1101/ pdb.prot095125] [PMID]

[28] Frackman S, Kobs G, Simpson D, Storts D. Betaine and DMSO: Enhancing agents for PCR. Promega Notes. 1998; 65:27.

[29] Nagai M, Yoshida A, Sato N. Additive effects of bovine serum albumin, dithiothreitol and glycerolon PCR. Biochem Mol Biol Int. 1998; 44(1):157-63. [DOI:10.1080/15216549800201172] [PMID]
[30] Bachmann B, Lüke W, Hunsmann G. Improvement of PCR amplified DNA sequencing with the aid of detergents. Nucleic Acids Res. 1990; 18(5):1309. [DOI:10.1093/ nar/18.5.1309] [PMID] [PMCID] 
This Page Intentionally Left Blank 